\title{
Agile and Lean Six Sigma Integration: a Leadership Framework
}

\author{
Alessandro Laureani \\ Independent Lean Six Sigma Scholar, Ireland \\ alaureani@hotmail.com
}

\begin{abstract}
Purpose

The purpose of this paper is to illustrate how Agile methodologies and Lean Six Sigma can coexist and propose a Leadership framework to successfully merge Agile methodologies with Lean Six Sigma practice.

\section{Design/methodology/approach}

The paper builds on the author's doctoral thesis on Leadership for Lean Six Sigma, and integrates Agile practices based on the author's experience in the software development industry.
\end{abstract}

\section{Findings}

Agile methodologies, that came to prominence in the software development industries from the early 2000s, can successfully coexist with Lean Six Sigma and positively reinforce the respective strengths, provided the right type of Leadership is in place to facilitate this integration.

\section{Practical implications}

Leaders in digital high tech organizations have come to consider Agile methodologies as the defacto standard in software development projects, and may have reservations on how Lean Six Sigma can successfully integrate with Agile: this paper proposes a framework for leading the integration of Agile and Lean Six Sigma practices.

\section{Originality/value}

The paper presents a framework for successfully integrating Agile and Lean Six Sigma: this would be of particular interest to practitioners in digital high tech and or software development organizations.

Keywords: Agile, Leadership, Lean Six Sigma

Paper type: Conceptual paper 


\section{$8^{\text {th }}$ INTERNATIONAL CONFERENCE ON LEAN SIX SIGMA}

\section{Introduction}

Agile methodologies, that came to prominence in the software development industries from the early 2000s, are now widespread in many different industries, where they are being used in place of more traditional project management techniques.

The purpose of this paper is to illustrate how Agile methodologies and Lean Six Sigma can coexist and propose a Leadership framework to successfully merge Agile methodologies with Lean Six Sigma practice in organizations.

\section{Agile}

Agile as a project management methodology was formally codified in 2001, when 17 representatives of the software development industry met in Snowbird (Utah, USA) to discuss future trends in the industry.

They noticed that the different iterative and incremental methods they had informally used since the 1960s and 1970s had many characteristics in common, so they formalized these commonalities and produced what came to be known as the 'Agile Manifesto' (Kaushik, 2016).

The Agile Manifesto states that priority should be given to "individuals and interactions over processes and tools, working software over comprehensive documentation, customer collaboration over contract negotiation, and responding to changes over following a plan" (Beck et al., 2001).

The Agile Manifesto also outlined the following 12 principles (Beck et al., 2001):

1. Our highest priority is to satisfy the customer through early and continuous delivery of valuable software.

2. Welcome changing requirements, even late in development. Agile processes harness change for the customer's competitive advantage.

3. Deliver working software frequently, from a couple of weeks to a couple of months, with a preference for the shorter timescale.

4. Business people and developers must work together daily throughout the project.

5. Build projects around motivated individuals. Give them the environment and support they need, and trust them to get the job done.

6. The most efficient and effective method of conveying information to and within a development team is face-to-face conversation.

7. Working software is the primary measure of progress.

8. Agile processes promote sustainable development. The sponsors, developers and users should be able to maintain a constant pace indefinitely. 


\section{$8^{\text {th }}$ INTERNATIONAL CONFERENCE ON LEAN SIX SIGMA}

9. Continuous attention to technical excellence and good design enhances agility.

10. Simplicity - the art of maximizing the amount of work not done - is essential.

11. The best architectures, requirements and designs emerge from self-organizing teams.

12. At regular intervals, the team reflects on how to become more effective, then tunes and adjusts its behaviour accordingly.

Despite having been originally formalized within the software development industry, Agile methodologies are gaining popularity in many other industries, being suitable for many situations and environments (Kaushik, 2016).

There are many versions of agile methodologies such as Scrum, Crystal, Feature Driven Development (FDD), Dynamic Systems Development Method (DSDM), and Adaptive Software Development (Hoda et al., 2008).

\section{Scrum}

Scrum is among the most known and adopted agile methods (Dikert et al., 2016) and it is characterized by teams given significant authority and responsibility for many aspects of their work, such as planning, scheduling, assigning tasks to team members, and making decisions (Brede Moe et al., 2009): essentially, the team organizes itself and makes the decisions concerning what to do.

The roles involved in a typical scrum team are Product Owner, Scrum Master, and the team members: the Product Owner is responsible for maintaining the correct business perspective and prioritize work items, while the Scrum Master acts as a facilitator for the team, removing roadblocks and ensuring they have the resources needed to perform the work works (Hoda et al., 2008). The team size is usually small (less than 10 people) and there is a preference for the team to be co-located, so to share ideas and iterate fast.

The work is usually organized in 'sprints' of a duration between 2 to 4 weeks of development time, and the Scrum Master leads a daily 15 minutes meeting where each member briefly describes their tasks and concerns (Hoda et al. 2008).

\section{Lean Six Sigma and Agile integration}

The term 'Lean Six Sigma' started to be used in 2000 as a way to describe the integration of Lean and Six Sigma philosophies (Sheridan, 2000) as a business improvement methodology that aims to maximise shareholders' value by improving quality, speed, customer satisfaction and costs.

In parallel to this, the adoption of Agile, since its formalization in 2001 (Beck et al., 2001), as a project management methodology has been steadily increasing, across many industries, to respond to increasing pressure on organizations to make products, or provide services, more quickly and with the fastest delivery time possible (Kovach et al., 2005). 


\section{$8^{\text {th }}$ INTERNATIONAL CONFERENCE ON LEAN SIX SIGMA}

As current global markets require a simultaneous focus on efficiency and quality, as well as flexibility and new product development, there have been attempts to adopt Lean Six Sigma and Agile at the same time for organizations to be able to deliver high-quality and customized products/services in the fastest time and at the lowest cost (Kovach et al., 2005).

Although it may seem that Lean Six Sigma and Agile tend to pull the organization in different directions, with Agile favouring flexibility, adaptability and fast iteration, and Lean Six Sigma favouring instead a more methodical approach, with typically longer project times and a focus on process standardization, Laureani and Antony (2021) showed how the two approaches can work well together.

Agile can be used for designing new products and/or services to meet customers' demand and as an overall portfolio management technique, keeping a prioritized list of projects and initiatives for the organization to work on; while Lean Six Sigma can be used to ensure high quality in the production and delivery of products and services and address the gaps identified from customers' feedback (Laureani \& Antony, 2021).

\section{Leadership framework for Lean Six Sigma and Agile integration}

The importance of leadership has often been emphasised by writers in the continuous improvement field (Waldman, 1993; Dean \& Bowen, 1994; Deming, 1994), and research has shown that effective leaders have distinctive traits that are a prerequisite for individuals who want to become effective leaders (Kirkpatrick \& Locke, 1991).

Adopting Lean Six Sigma and Agile together requires effective Leadership to balance the speed of Agile and the rigour of Lean Six Sigma: in this section we'll first illustrate the characteristics of effective Leadership for Lean Six Sigma and Agile respectively, and then we illustrate the proposed combined Leadership framework for an effective integration.

\section{Leadership for Lean Six Sigma}

Laureani \& Antony (2017) have identified the Leadership traits that are more conducive to a successful deployment of Lean Six Sigma in organizations:

- Visibility

- Excellent Communicator

- Inspirational

- Three Rs (Roles, Responsibilities, Relations) clearly defined

- Consistent

- Targeted

- Building a philosophy, a way of working 


\section{$8^{\text {th }}$ INTERNATIONAL CONFERENCE ON LEAN SIX SIGMA}

- Leading by example

- Flexible

- Three Cs (Connection, Competence, Character)

Although some of these Leadership traits were present in the vast Leadership literature, their unique arrangements effectively form a new Leadership style for an effective deployment of Lean Six Sigma in organizations.

Laureani \& Antony (2021) further describes the practical behaviors that an organization leader should display at different stages of a Lean Six Sigma deployment, and introduce the Leadership model outlining that the more service-centred the sector and the smaller the company, the greater the need for strong leadership to successfully implement Lean Six Sigma.

\section{Leadership for Agile}

The main characteristics of Agile are self-organizing teams and shared leadership (Brede Moe et al., 2009): these pose unique requirements on the type of Leadership needed for successful Agile implementations.

Self-organizing teams are teams that monitor and manage their own performance, make decisions related to their work, and take collective responsibility for meeting their own goals (Hoch \& Dulebohn, 2017): self-organizing teams have been found to stimulate participation and involvement, resulting in greater commitment, motivation to perform and desire for responsibility (Fenton-O'Creevy, 1998).

Although the members of a self-organized team are largely on their own, they are not uncontrolled, and management should establish checkpoints and guidelines, while avoiding the kind of rigid control that impairs creativity and spontaneity (Takeuchi \& Nonaka, 1986).

For the team to be self-organizing, leadership needs to be shared, rotating to the person with the key knowledge and skills for the issue at hand (Brede Moe et al., 2009): the team leader should be responsible for designing the team, clarifying purpose, articulate vision and securing resources (Langfred, 2000), but should then empower the team in choosing how to get the job done.

Transitioning to self-organization is described as challenging for both the team and the overarching organization (Dikert et al., 2016) and it requires the rise of emergent leadership, where team-internal leadership is not formally designated but emerges within the team (Przybilia et al., 2019). 


\section{$8^{\text {th }}$ INTERNATIONAL CONFERENCE ON LEAN SIX SIGMA}

Most of the challenges in deploying Agile methods (Dikert et al., 2016) are similar to the ones encountered in Lean Six Sigma deployment (Albliwi et al. 2014): resistance to change, skepticism towards the new way of working, top down mandate creating resistance, lack of training and coaching, misunderstanding of agile concepts and poor projects selection and prioritization are critical failures factors for organizations wanting to deploy either Lean Six Sigma or Agile.

Similarly, most of the critical success factors for Agile deployment (Dikert et al., 2016) are the same as the critical success factors for Lean Six Sigma deployment (Laureani \& Antony, 2012): management commitment, communication, awareness, training, and leadership are critical success factors for organizations wanting to deploy either Lean Six Sigma or Agile

Leadership is a critical success factor for both Lean Six Sigma and Agile, and the Leadership traits for a successful Lean Six Sigma deployment (Laureani \& Antony, 2017) are also mentioned in the literature for Agile leadership (Dikert et al., 2016): organizational leaders that want to successfully deploy Agile in their organization need to be visible, excellent communicators, consistent, targeted, inspirational, clearly defining roles and responsibilities, build a new way of working, leading by example, being flexible and adapt during the deployment, and gaining trust through connection, competence and character.

The biggest Leadership difference between Lean Six Sigma and Agile is the concept of emergent and shared leadership in projects: leadership in Agile is expected to emerge from attributions based on cognitive skill and being knowledgeable (Taggar et al., 1999), rather than being officially appointed.

Emergent leaders are individuals who exert significant influence over other members of the group, even though they may not be vested with formal authority (Hoch \& Dulebohn, 2017): emergent leadership within agile teams emerges in a shared form with more than one member perceived as leader (Przybilia et al., 2019), and Leadership attributions based on function (Przybilia et al., 2019).

Shared leadership is defined as a collective leadership process, whereby multiple team members step up to take the lead or to participate in team leadership functions (Hoch \& Dulebohn, 2017): essentially, in Agile teams, different team members became emergent leaders depending on the task at hand.

While this refers to leadership within a project team, and it differs from the typical Lean Six Sigma project leadership of a Black Belt or Master Black Belt, Agile development at organizational level needs to put self-organizing teams at the center and foster an environment of informal communication, with a focus on facilitation through an integrated and democratic style of leadership (Stewart et al., 1995).

The Agile iterative approach requires recognition and acceptance from the organizational leadership as well, acknowledging that not everything can be known and planned for, and that the best way to implement is to adjust as you go (Brosseau et al., 2019). 


\section{$8^{\text {th }}$ INTERNATIONAL CONFERENCE ON LEAN SIX SIGMA}

For the self-organized teams, and shared leadership, to be successful, organizational leadership also needs to ensure team members have the right level of skills and ability to effectively not only perform the task at hand, but to be leaders: continuous self-organizing requires effective mechanisms for learning and capacity to adapt operating norms and rules to transformation in the wider environment (Brede Moe et al., 2009).

Empowerment of self-organizing teams and an iterative mind-set are two new Leadership traits that organization leaders need to display in order to facilitate Agile deployment: these are in addition to the Lean Six Sigma leadership traits already identified (Laureani \& Antony, 2017).

\section{Conclusion and agenda for future research}

Agile and Lean Six Sigma have developed independently and reached widespread use across many industries and organizations in the past 20 years: although it may seem at first that each tends to pull the organization in different directions, Laureani and Antony (2021) showed how the two approaches can work well together.

This conceptual paper has introduced the main characteristics of Agile and the Leadership traits identified in the literature as more conducive to a successful deployment of Agile methods in organization.

In comparing this to the Leadership characteristics for Lean Six Sigma deployments (Laureani \& Antony, 2017), it suggests there is an overlap between the two, with two additional Leadership traits needed for Agile deployments: the ability to empower self-organized teams and an iterative mind-set.

As this was a conceptual paper, it needs to be validated with research in the field, in order to build a systematic understanding of Leadership processes and Agile methods: a mixed method approach, combining qualitative and quantitative methods, is suggested.

First step would be a quantitative study, survey based, to investigate among practitioners the impact of Leadership on Agile methods and factors for sustaining Agile across organizations of different sizes and industries. This will be followed by a qualitative study, with semi-structured interviews conducted with Agile practitioners, across different industries, geographies and hierarchy levels, to investigate what specific Leadership traits are more conducive to a successful deployment of Agile methods.

Implementing Lean Six Sigma and Agile together will be a challenge for many organizations, requiring Leaders to balance between the speed of Agile and the rigour of Lean Six Sigma, but the reward can be highly flexible and accurate processes that adapt to constantly changing customer demands (Laureani \& Antony, 2021). 


\section{$8^{\text {th }}$ INTERNATIONAL CONFERENCE ON LEAN SIX SIGMA}

\section{References}

- Albliwi, S., Antony, J., Lim, S., van der Wiele, T. (2014), "Critical failure factors of Lean Six Sigma: a systematic literature review, International Journal of Quality \& Reliability Management, Vol. 31, No. 9, pp. 1012-1030

- Beck, K., Beedle, M., van Bennekum, A., Cockburn, A., Cunningham, W., Fowler, M., et al. (2001), Manifesto for agile software development. <http://agilemanifesto.org/>

- Brede Moe, N., Dingsøyr, T. \& Kvangardsnes, Ø. (2009), "Understanding Shared Leadership in Agile Development: A Case Study", 42nd Hawaii International Conference on System Sciences - Proceedings, pp. 1-10

- Brosseau, D., Ebrahim, S., Handscomb, C. \& Thaker, S. (2019), The journey to an agile organization, McKinsey report <https://www.mckinsey.com/businessfunctions/organization/our-insights/the-journey-to-an-agile-organization\#>

- Dean Jr., J. W., \& Bowen, D. E. (1994), "Management theory and total quality: Improving research and practice through theory development", Academy of Management Review, Vol. 19, No. 3, pp. 392- 418

- Deming, W. E. (1994), “Leadership for quality”, Executive Excellence, Vol. 11, No., 6, pp. $3-5$

- Dikert, K., Paasivaara, M. and Lassenius, C. (2016), "Challenges and success factors for large-scale agile transformations: A systematic literature review", Journal of Systems and Software, Vol. 119, pp. 87-108

- Fenton-O'Creevy, M. (1998), "Employee Involvement and the Middle Manager: Evidence from a Survey of Organizations" Journal of Organizational Behavior, Vol. 19, No. 1, pp. $67-84$

- Hoch, J. E. \& Dulebohn, J. H. (2017), "Team personality composition, emergent leadership and shared leadership in virtual teams: A theoretical framework", Human Resource Management Review, Vol. 27, No. 4, pp. 678-693

- Hoda, R., Noble, J., \& Marshall, S. (2008), “Agile Project Management”. In J. Holland, A. Nicholas, \& D. Brignoli (Eds.), New Zealand Computer Science Research Student Conference, NZCSRSC 2008 - Proceedings, pp. 218-221

- Kaushik, A. (2016), “A literature review on Agile Software Development", International Journal of Advanced Research in Computer and Communication Engineering, Vol. 5, No. 9, pp. 337-339

- Kirkpatrick, S. A., \& Locke, E. A. (1991), "Leadership: Do traits matter?", The Executive, Vol. 5, No. 2, pp. $48-60$

- Kovach, J., Stringfellow, P., Turner, J. \& Rae Cho, B. (2005), "The house of competitiveness: the marriage of Agile manufacturing, design for Six Sigma, and Lean 


\section{$8^{\text {th }}$ INTERNATIONAL CONFERENCE ON LEAN SIX SIGMA}

manufacturing with quality considerations", Journal of Industrial Technology, Vol. 21, No. 3, pp. 2-10

- Langfred, C. W. (2000), "The Paradox of Self-Management: Individual and Group Autonomy in Work Groups," Journal of Organizational Behavior, Vol. 21, No. 5, pp. 563585

- Laureani, A., Antony, J. (2012), "Critical Success Factors for the Effective Implementation of Lean Six Sigma”, International Journal of Lean Six Sigma, Vol. 3, No. 4, pp. 274-283

- Laureani A., Antony, J. (2017), "Leadership characteristics for Lean Six Sigma", Total Quality Management \& Business Excellence, Vol. 28, No. 3-4, pp. 405-426

- Laureani, A. \& Antony, J. (2021), "Integrating Innovation, Agile and Lean Six Sigma”, in Leading Lean Six Sigma: Research on Leadership for Operational Excellence Deployment, Bingley, UK: Emerald Publishing

- Przybilia, L., Wiesche, M. \& Krcmar, H. (2019), "Emergent Leadership in Agile Teams An Initial Exploration”, Proceedings of SIGMIS-CPR '19, June 20-22, 2019, Nashville, TN, USA, pp. 176-179

- Sheridan, J.H. (2000), “Lean Six Sigma' synergy”, Industry Week, Vol. 249, No. 17, pp. $81-82$

- Stewart, G.L. \& Manz, C.C. (1995), "Leadership for Self-Managing Work Teams: A Typology and Integrative Model”, Human Relations, Vol. 48, No. 7, pp. 747-770.

- Taggar, S., Hackett, R. \& Saha, S. (1999), "Leadership Emergence in Autonomous Work Teams: Antecedents and Outcomes", Personnel Psychology, Vol. 52, pp. 899-926.

- Takeuchi, H. \& Nonaka, I. (1986), "The New New Product Development Game," Harvard Business Review, Vol 64, pp. 137-146

- Waldman, D. A. (1993), “A theoretical consideration of leadership and total quality management”, Leadership Quarterly, Vol. 4, No. 1, pp. 65-79 